\title{
篗聯科學院1953年科嚳工作 的基本總結
}

\author{
H. M. 西薩强
}

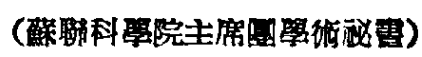

婜密地團結在共索黨和蘇維埃政府周畧的蘇 聯人民, 1953 年在自己祖國的雁史上寫上了新的 光策的一真。

1953 年墢展國比經湾國家計劃的執行情况 的總結表朋, 我國人民在琗固祖國威力、腾展國 家經湾文化和提高管動人民物質福利上獲得了新 的重大成就。

人民的利谷一造是融會主義社會的最高淮

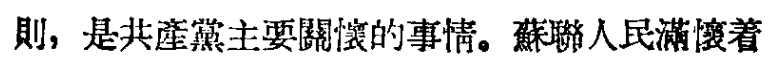
創造的熱性, 藇國一致地接受了黨所提出的戰閏

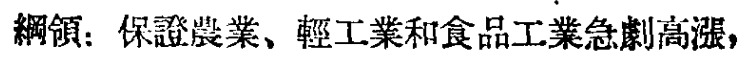
以便在最近幾年之內創立日用品的豐富供應。

蘇距人民滿滚信心地走向共産主義, 最高蘇 維埃的選舉荤動是破聯人民强大絰一的文一新的 證明。蘇維埃人在無此圈結的氣氛下將人民最便 秀的兒女，首先星黨和政府的領導者提名篇自己 的候選人。

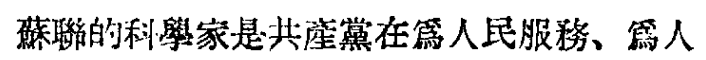

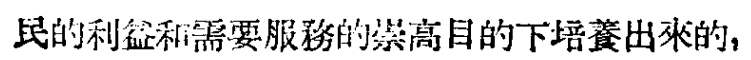
他們正在篇暂現第十九次黨代表大會、蘇聯最滈 蘇維埃籍五坎常會和蕉其中央九月全會的歷史性 决議以及黨和政府的㗨次决議而畧出自己的力量

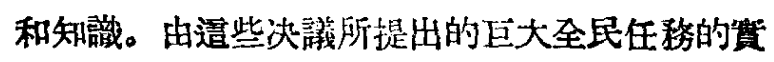

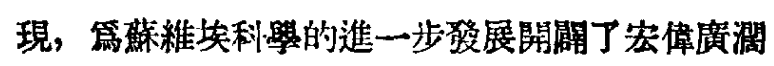
的遠景。

和以往各年一榡，我們黨的中央和葆聯政府

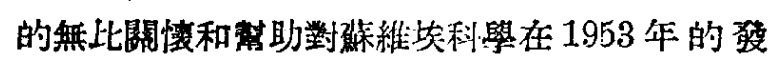
展有着非常重大的意義。

在 1953 年队蘚聯科學院獾得了新的巨大挜

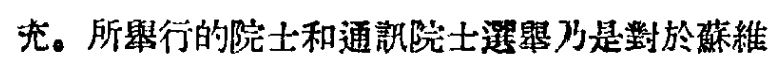

莫科學的成就及其幹部的成長的一次员正的全民 悉查。選出了51 位院士和 148 位通訊院士。科期 院遻是第一次獲得道樣大規模的補充。院士和通 訊院士的選舉促進了所有各個學部的萃固, 而物 理學數學部、地質學地理學部和技術科學部的成 員則得到了特别的摭充。

1953 年在科學院的系統下成立了無線電技 術研究所、電子學研究所和馨學研究所, 亚且通 過了成立元素有機化合物研究所和發動機賽驗空 的决議。堷些研究機構的成立將使我們能廣泛地 弱展一些大有前途的新科舆方向的研究工作。

在自然科億史研究所的基礎上成立了一個新 的自然科學與技鿉史研究所, 這個研究所已䌡提 整了一項研究和整理我國科器與技術史上各種豐 富史料的廣泛而多方面的計劃。

1953 年科學研究工作的一個知著特點 就是 比以往更廣泛地運用了新的技微和 新的研究方 法。由於利用了和同位素有關的標記原子方法、

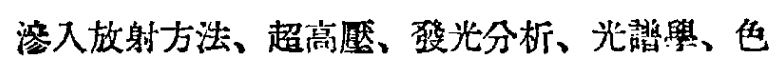

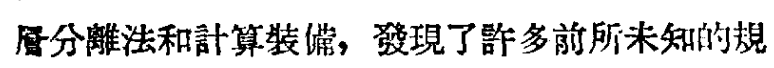
律.

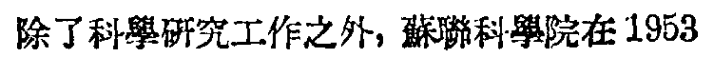
年還大力地進行了將科學的墢現和成果推行到國 民經济中去的工作。

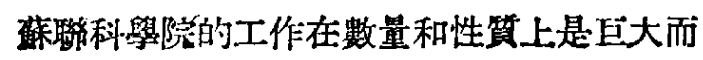
多方面的, 因此在總結報告裹只能阔述一些主要 的方面, 其中包括某些最有前途的開題的研究工 作的總結。

科學院 1953 年的研究計劃荥定研究大量的 閌題，包括将近 3,000 項研究題目。計劃中所规定 
的任務基本上都已完成; 還没有作完的題目有 97 個，其中包括詐多極篇重要的題目。

自然资源的調查研究 1953 年地質地理科學 面臨着巨大的任䅂, 造些任移就是進一步調查研

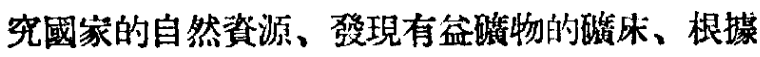

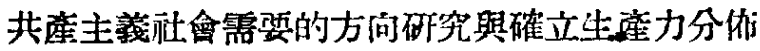
的原則，進一步弡展地筫地理科學的理論基礎。

解了解决塄些任務, 研究工作就應該在全國範園 內展開, 其中包括逆遠的和未開蒩的地澡。

對東部地區的研究已給予特別的注意，如烏 拉酮、哈茏克、西伯利亞等地。在這些地區, 蘇 聯科學院的科學家腾現了從前所不知道的砤林， 查明了新的、在造方面有筑展前途的地區。

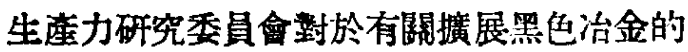
碏物原料基地的工作和利用詐多地區的水力資源 的工作進行了巨大的綜合性研究。在東部地區發 展交通運㻌和改進㤼查工作方法的研究, 也同樣 在國民經济中起着重大的作用。

根㨜黨的第十九次代表大會和蘇共中央九月 全會的决議, 制訂了在獾聯非黑土地帶（中部工

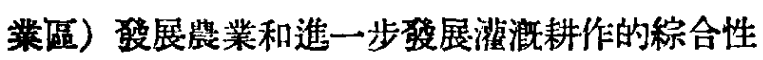
研究計劃。

海洋學研究所的考察隊獲得了靠近千島票島 的深水凹槽的新材料。凹槽動物莘, 種類媻多, 具有乳白色的特徽, 浐登明了動物辢所在的深度 是太陽光不能穿透到的。造個凹槽沿堪察加牛島 海岸向北延伸，因此它應賞稃篇千煘一堪祭加凶 槽地。道個地區有活䟾的地震, 進一步研究這個 新的大地槽酷域是有重大的理諭和害際價佔的。

關於總結性的工作㣹當指出的有: 遠東地區

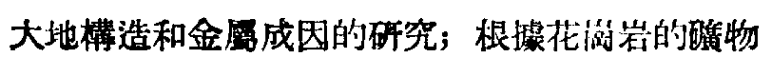

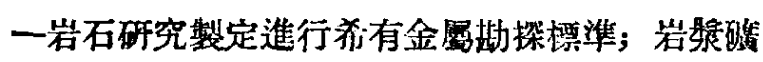

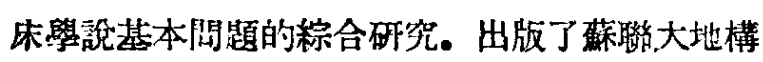
造圆，造是總結蘇聯大地構造資料的首次嘗試。

1953 年, 用同位素的方法桃决定岩石絕對年 战得到了很大的登展。

㯰應該指出，植物學研究所的在地質學方面 很有價值的一些著作: “西西伯利亞的上白惡紀 植物誌”和“阿秀泰斯山植物誌”。古生物學研究所 於西伯利亞陸台、㢈斯泊茨與米努斯出地古生 代地尽的研究工作對地筫學同樣是有很重要的意 转的。
關於要予以推廣的工作應舉出:

頓巴斯煤的微細結構和岩石的成因類型 㠇

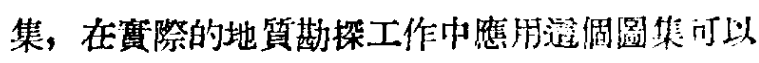

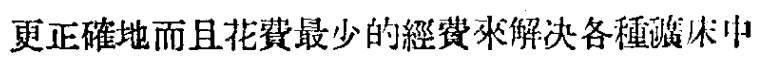
含蹀量的預测問題。

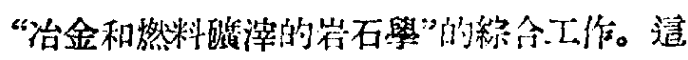

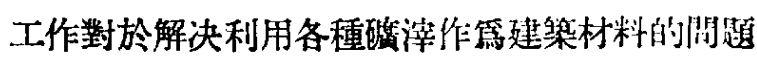
有很大的價值。

預測煤的圖表。

最重要的捕魚區的海洋學材料圖。這些圆使 我何有可能更有目的地進行魚場和踣魚的探的工 作。

地質舆研究所拖䢰了三個非常重要的研究題 目的完成，逪證明了對重要工作按時完成的督促 是溥搦的。

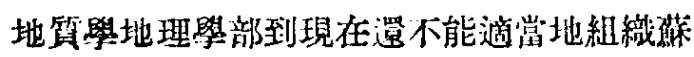
聯科學院、各加盟共和國科學院和各產業部门”的

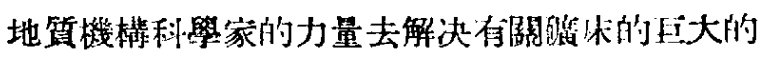
總結性的工作。由於製訂碑究工作計劃時的缺 點, 地理學䃑究所造成了工作人員間不平均的工 作負担，因此引起了部分計劃的不能完成。直到 現在, 題目零碎的現象澴传然存在，尤其是地理

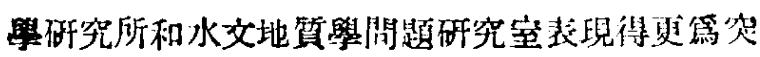

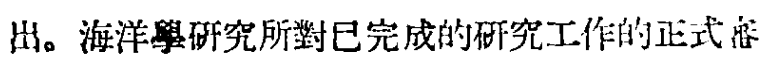
定做得不够䩗意, 在阿巴洛夫所传責的工作中就 有嚴重的缺點, 以致必須加以重新改作。

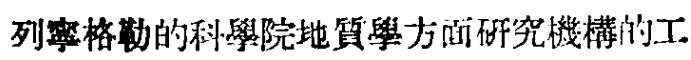
作中有很嚴重的缺點, 尤其是湖沼學研究公和寒 武紀地質學研究空, 它們的工作缺泛䈍有的方问 性和目的性。

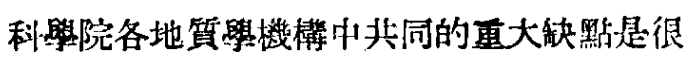
少展開有關發現希有元素和分散元素的原料基地 的工作。

在調配、總結與利用科䡆院所進行的考察工

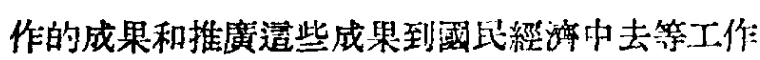
中, 生座力研究委員會到現在還沒有担負起他柤 担負的職責. 委員會的布略洔-蒙古考察隆和遠 東考察降的工作是在很目難的情况下進行的，而 且沟有得到應有的成功; 在它們的工作中科學领 導不强, 科學幹部配借不足, 没有經常與科學院

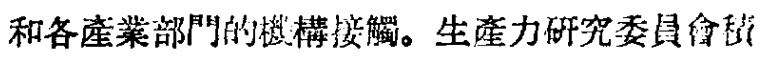

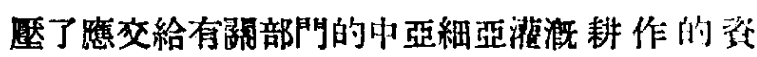


料。

物理罢數管方面的問題 1953 年在物 理學 方面研究了宇宫線、牛䆃體、發光現像、計算技 術和天文學的一些重大問題等等。在聲學方面， 大大地摭大了一些極重要問題的研究陣容。

1953年在射電天文學和射電光部罢兩㩔新的 研究方向上進行了工作。射電天文學提供了認識 宇宙的一種完全新的方法, 並且正被應用到其他 很多的赛際工作襄去。射電光謵學也有着不小的 意義。狺方面的工作是由科學院喀山分院與物理 舆研究所担虽, 發現了一些新的規律, 但所作的 還遠不够。

在牛導體放大器與整流器的結構設計方面得 到了一些成就。這些昆體儀器, 比起那些由或空 管製成的有很多的優點: 構造簡單, 堅固, 體積 小，工作時榣定性大和使用期久。

1953年物理學家的最重要的成就之一，是關 於材料機㥇性能的理論研究, 這,是由利罗院的技 術一物理學研究所進行的。由於造些研究的成果, 使我們能够用新方法隶解决很多建築結構上的計 算問題，並同封考䈍到對這些結構的使用期限的 要求; 使我們能够有意識地選摆各種結構的最好 工作佟件，並避炛因加大安全係數而白白浪费掉 很多材料。

地球物理學政究所有成效地政究着並試驗着 在野外洞杏的條件下進行测量地震的新方法: 地 震研究的相閣方法和地款深處的地震探測法等。

海洋物理學㸴究所第一次阙明了在風的作用 下，水派的波長増長的原因及其規律。水波傳播 的功率已用新理論計算出來, 所得的結果興實驗 数據很符合。

數學硼究所在代數方䤄獲得了重大成果, 進 行了改進機率部與鞂理統計的極限定理的研究。

精密機械與計算技術研究所在大型計算機的 應用可能性與新型問題的規劃方面也進行了研 究。

在天交眙方面，對太陽物理學完成了重要的 研究。在狌際物質與星雲方面也進行了研究。

1953年推廣了一些㸴究成果, 如結晶學研究 所對蘇聯日用品工業部的一些企業推廣了在人造

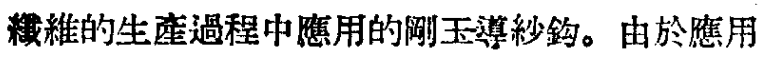
了逭種罧紗鈎而大大地提高了生產率。
物理學數學部的工作存在着䂭重的缺點。值 到現在學部對各研究所的提出與進行砳究工作未 保䇺有效的領䆃, 未深入到各研究所的工作中 去。海洋物理學研究所竟没有一個研究成果推廣 到國即經流中去。“地球物理學研究所也拖延了磁

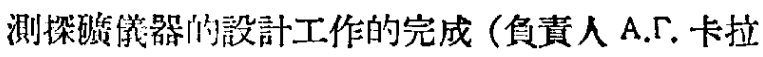
式尼可夫敎授)，對天氣的長期預報問題解决得很 不够，還遠不能滿足國是經濟對造方面的要求。

對待科學任務的完成，有個别潦营從事的情 况。如物理學數學博士 H.A. 霍沃斯其可夫接受了 重要問題的研究工作，但在他的資驗㤼犯了很 大的錯㛊（這是不久前才琵清楚的）。遭又一次地 提醒星我們各研究所的學術委員會，應該好好地㸝 强對研究工作的監督; 不僅要對䂯究工作的計劃 與結果進行密䄳，也要仔細地分析得州這些結果 時所用的方法。

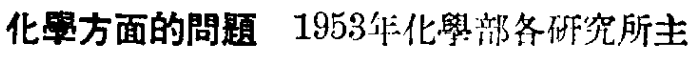

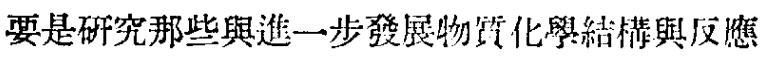
性能的理論、多相俳化理諭以及與建立工業嶵化 過程的科學原理有關的問題。化罢部各主要研究

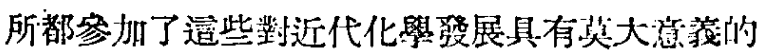
綜合性㸴究工作。已經在元素有機化合物、高分 子化合物化學方䤄獲得了成就，並且有效地進行 了絡合物化學、矽酸監化學、地球化學以及其他 方面的工作。

有機化學硎究所在研究多維合過程——例如

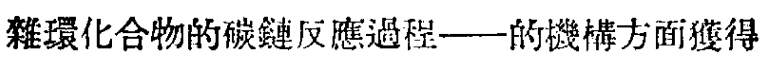
了新的數娽，利用管些数據可以進行硼究新合成 方法及現有高聚物的性質。

在研究乙烯溶液聚合的基礎上，研究了製储

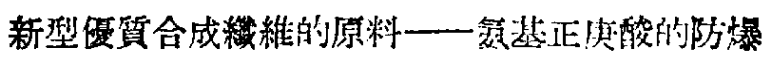
慗法。利用這種方法已做過模型試驗, 取得了設 計中間工凮必要的数據。

高分子化合物研究所合成了新型樹脂，邆種 樹脂有很高的粘附力和膠粘性。䌈渦試驗篮明, 樹脂可在汽事工業和磨场材料生産中作第鉛錦料 的代用品。

硫化的反應機構的研究工作，提供了從合成 橡膠製取具有良好機械性能的橡膠的賽用方法。

普通與無機化學研究所在絡合物的研究工作 中，確定了絡合物中原子相互作用的新的細范（對

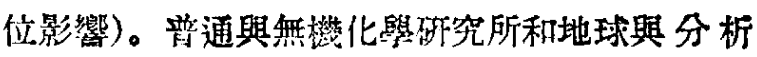


化學研究所開始了希有元素和分散元素化舉以及 選些元素的地球化學、分析化學方面的棕合性間 題的研究工作。

有機化學研究所、物理化學研究所和化學物 理䝿研究所在催化作用方面的研究使我椚得到了 可以確定選擇催化劑的新的原則和南明烴類接触 催化轉換機構的新規律的許多重要實驗資料。通 些資料對於合成櫢膠工業和石油的催化精煉具有 極窟重大的意義。此外還進行了紫備異戌二烯方 法的擴大試驗, 異戊二桸是構成天然橡膠的基本 單位。

在部多化學問題的研究中，廣沉地隹用了同 位素的研究方法, 這種方法等助完成了許多具有 重大科學和實用意義的工作，使我們得以深入到 物䓄的化學結構中研究其動力學和反應性能。遭 方面的一些成果, 如試制的純度的控制方法, 已 推廣到化㹕工業中。

在工廠中完成了麻醉劑“普羅嘧陀”彆法的推 廣工作。在保健部的工廠中完成了鏈微素無碳分 離精整法的推席工作。

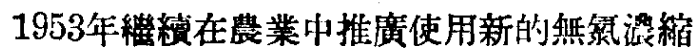
巴料。但在生库條件下來試驗這些肥料的工作進 行得異常啲緩。

在化學研究所的工作中也倷在着一些缺點。 普通與無機化學研究所在研究乔有元素和分散元 素的工作中, 在基本方向方面没有獲得應有的進 展. 逐方面的工作以及阔分子化合物、矽有機化 合物和其他化合物的化學興物理學方面的工作，

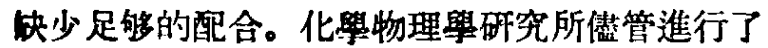

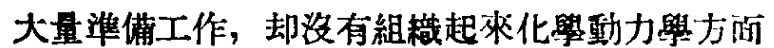
的會議了該所很少注意研究化學反應機構、中間 廉物結構的近代的研究方法的發展, 他們在光化 和質譜方面的研究工作也進行得很不够。催化 作用方面意義重大的研究工作被分成零星的小題 目，皘累了的大量蒉驗資料也未加以整理。

技彷科量問题 强大的蘇維埃社會主義工業 是我國人民偉大的勝利果實。只有在社會主義工 莱不斷展的基礎上，才有可能筫現茄會主義生 座的最漓法則一一最大地滿足塥會需要。黨的第 十九次代表大會的指示要求: 集中科學研究及筫 用工作方面的創造力量, 有效地解决先進社會主 素工的問題和垔用新的興最新的科學拔術。
在 1953 年中，我國機器繁造業尺㓣造了 700 多種最重要的新式機械, 其中有輕工業和食品工 業方面 100 多種具有最离生產效力的新型機械裝 借。

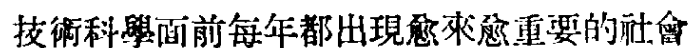
主義工栄㩰術所急需解决的理满問題。

1953 年, 科學院在渦輪發電機製浩的㸴究、 冶煉用新固體燃料和加速冶煉過程的研究、㰾造 新的和改進整的䌘造機器所用特種合金的研究、 提高從碳石中提取金屬的綜合回收率和整造弡動 機燃料與發動機用油的䟭究、生崖過程全面機械 化的研究和逶距離輸電問題（首先是配合古比雪 夫及斯大林格勒水力發電站建設方面的遠距離輸 電問題）的㸴究等方面，都得到了㙷著的發展。

動力研究所筸硼究了發屡動力系統的科基

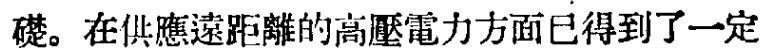

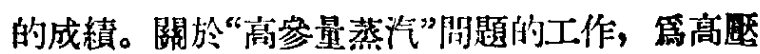

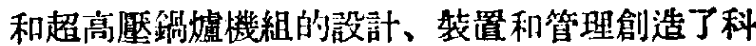

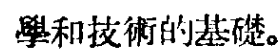

自動控制和遠距離操縱研究所進行了許多有 關自動控制和調節動力系統的工作，製成了比外 國貨具有更多優良性能的電子射線偖器。就其䍚 用的可能性來馀, 這些儀器是萬能的, 並有希壁 廣泛地用來解决自動控制、蒸距離操縱以及計算 技街等方面的問題。

運用斷繶控制理論可以研究多種自動調節系 梳，在道方面的工作第一次得出了可靠的計算的 方法。

石油研究所已完成了用氧化烷瘙烴的方法整 造高級脂肪醇的重要工作。這個工作使独聯出現

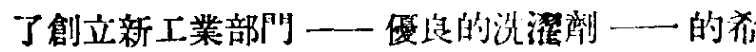

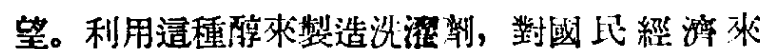
說, 可大大地篩約食用油脂。石油硼究所又進行 了用石油、煤及煤氣製造涪質量燃料和潤滑游的 研究。創造了新的發動機穄料和從汁分紀石油製 造燃料的方法以及重油原料加工的合理步㵵等。

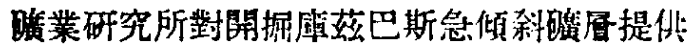

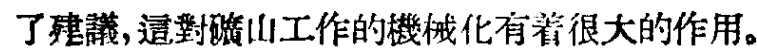
治金研究所已成功地研究了有阔败鑄生鐵的

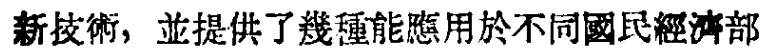
阴的新的高性能合金。

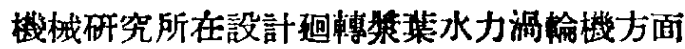


已提供了建議。

研究水利問題的工作組已完成了多年乘有關

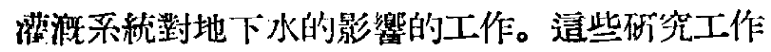
篇探取賽際措施以改善大塊灌澌地土壤改良工作 打下了基礎。利用預测修建灌溉系統後地下水情 况的方法, 可以預知土壤的卧化和沼澤化, 並調 節地下水流。

1953 年繼續順利地進行了有關同位素及滀 入放射應用於各種技街部阴的研究。在用造個方 法而完成的許多最重要的工作中, 應該指出的是: 通過這些硼究已得出了冶煉過程的機構和動力學 方面的資料。這些資料使得科學研究能在我國大 規模冶槵企業的生產條件中進行。用標㲹原子來 研究金屬及合金的援散和自援散的工作，對了解 决定合金强度的基本因素及研究合金製造理論起 着很大的作用。

用放射性同位素來研究機器中活動零件的脴 損他是很有齐然的。在㤫用放射性䡚射的基礎上 已製成了测量、控制及調整詐多技術過程的儀器。 可造泾的是逭方面的大部分工作都不是在科學院 各研究所完成的, 而只是在科學院的科學工作者 寥加下完成的。

在已紃荤用於筫際的許多最重要的工作中, 可以舉出以下的例子:

然料砤物研究所的焚氣化過程强化方法, 使 煤氣發生裝置的生產率增加到 $1.5-2$ 倍。

燃料碾物研究所所提出的大量去除煉焦煤中 灰分和砝分的新方法 (離心選酸法)，一方面能枯 出含雜質低的煉冶燃料（這樣使高䲣的生產率至 少增扣 10\% ，，一方面大大地演大了可用來媡焦 的煤的種類。

燃料碳物研究所研究了用水煤釆的接䐺甲烷 化來製得城市用煤氣的方法。逭種方法能在没有 天然煤氣和煉焦煤氣來源的城市和鄉賖中運用。 篇了保證有高發熱量的煤氣, 該法目前已用於蘇 聯發電站及電気工業部的許多工歌中。

自動機械與遠距離操縱機械研究所和阿塞拜

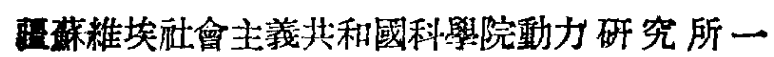
道, 研究了自動控制涯縮採油井的方法, 使石油的 荓探量增加了 $3 \%$ 。這個方法已運用到生產上了。

冶金研究所和機械研究所等成了可供汽車和 挴拉機發動機軸承用的鋁合金，大大地節省了有
色金屬（銅、鉛、錫）。

酉部西伯利严分院所提出的在堅硬岩石琵鉷 深生產井用的銓機, 能快速鑽出深篇 40-50 米、 直徑第 100-120 笔米的監井、斜井和水平井, 速 率窟 70-80 毫米/分。應用鑽探機已使鎮探工人 的勞動生产率坦加到 $2-3$ 倍, 並降低了探掘酸 石的成本。

1953 年, 技術科學部門有一些重要工作没有 按期完成, 技術科學方面重大理論研究題目的數 量還是很少的。各研究單位至今還不能成蘦在工 業中墢展和運用標記原子法的倡燥者, 它們對應 用標記原子法的新途徑研究得還很少。

自動機械與遠距離操㧿機械研究所䢱没有對 電報和電話的自動化问題給以應有的注意, 生座 過程自動化方面的研究工作的速度還是不够快。

機械研究所對總結工業方面的先進經驗做得 還不够。

在技政科學部門各研究單位的工作中，有着 與蕗聯科學院其他各單位的聯系不够和棕合性的 研究題目很少等不良情况。

生物翼問題 由於黨和政府關於進一步㡎展 農業、輕工業和食品工業的一切部門的决定, 提 出了許多科學上的開題; 在研究逜些問題時, 在 米丘林生物學和巴甫洛夫生理學的琶固的唯物主 義基礎上發展起來的我國生物科眐佔有主要的地 位。

10月，科揫院主席葍通過了一個特别决定: 探取措施來改善各科學機構協助整業和日用品工 業的工作。雼了把已經完成了的研究工作廣泛推 行到農業中去, 已經確定了一項名單。同時並指 出了需要立刻加以研究的科嚳闍題。科研究工 作計劃中添加了近 70 個題目。對非墨土地帶的 農業（土壤改良、密植、馬鈴著和蔬荣屋量的提 高、畜牧業的發展等), 在我國水海發展漁業等問 題的研究正在擴展。在科學院各研究所和各分院 內正廣泛召開有關最迫切問題的專業會議（抗生 素、農作物和農畜的病害防治等)。並準備要出版 有紫费作物和農畜的生物學方面的通 俗科學小 册。零了加强農業方面的工作，粗織了各種央門 性的考察隊; 生物學各單位的實驗基地正在擴充。

在 1953 年, 植物生理學研究所用色居分淮法 及標副原子方法確定了根系在氮基酸最初合成時 
所起的重要作用，阙明了春小麥在灌溉佟件下闹 化座物轉移的方向及速度。這些呼究有吸於對植 物體內生理過程控制方法的擬定, 也有助於施肥 方法合理化及其他方面。

遺傳學研究所的小麥定向数異的研究登明 了：從同一春化性類型，但在我國不同氣候區域 內所獾得的冬小娄具有不同的酎寒性。1953 年的 觀察證朋了在鄂木斯克的條件下從春小麥所獲得 的冬小装是最能抗塞的。該所賽驗又證明了: 只要 促使熙鈴著地落的新芽從較深藏的組織墢育, 即 能堛育出具有新遺傳性的類型。因此已獾得了若 干具有有經沾價做的性狀及特性的馬鈴著品種。

生物化學研究所確定了: 由於棐線素及其他 色素的最初记反虑而形成了高度活性的光還原產 物，也指出了這些活性化合物和光合作用過程中 酶期的聯結過程。由於應用了碳同位元素 $\mathrm{C}^{14}$, 橆 現並研究了植物渠中固定二氧化碳的最初產物, 也查明了植物根部吸收二氧化碳的一些反應的本

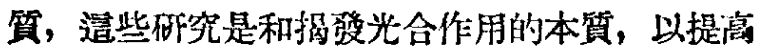
座量的阙題密切聯系着的。

微生物學研究所完成了部多有助於農業發展 的研究工作。特別是瞭解了在紫花当堦的多年種 植以後所產生的楾花的抑制現象是由於紫花自管 分泌到土培中去的毒素所引起的。因此提出了縮 短紫花当㴼在棉一紫花亘诲輪作中的時間的建議。 解决了在费作物病害防治中利用抗生素的可能性 問題。

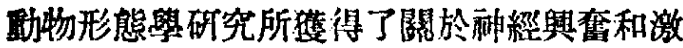
恋性的機構的有意義的資料。

生理學研究所、高䋇视縚活動研究所和生理

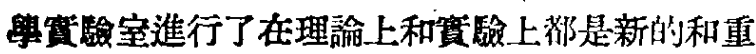

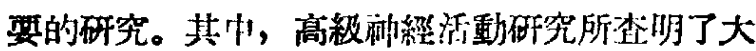
盿皮居動力中，特別是第一和第二信號系統的相 互關係中的特殊變化。

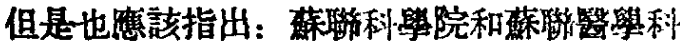
蚂院聯庹合議篇創浩性地發展巴甫洛夫生理學開 周了廣濶的可能，而造些可能還裳没有被我們的 生理學家所充分利用，特别是在高叔神經活動的 研究方面。創造性的知動和創造性的短論常常被

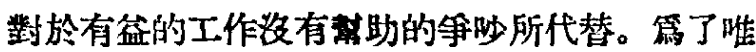
物的巴术洛夫生理學的發展, 迫切需要全蘚梅生 理學界的㪀䛎的和創造性的努力。
在科學院所有生物學矼究機構中造沟有廣泛 地運用新的科究方法: 如電子㙷微鏡方法、闬位 元素法及其他。踓然大家都知道, 正因篇利用了

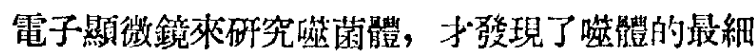
緻的結構。

生物學部所進行的部多工作已推廣到生 產 中。

生物化學研究所已把二種新的維生素—一維 生素 $\mathrm{P}$ 和維生素 $\mathrm{B}_{12}$ 一一的型造技衙在工業中推

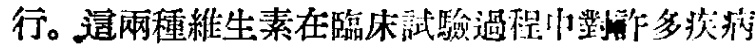
的治㙩效力極高，特别是維生素 $\mathrm{B}_{12}$ 對於等性算 血是一種有效获贸。

已紃進行了多年的、關於在工業叫推行對茶 生產的生化控制的工作，在 1953 外已經完成。亚 且創造了製取一種新型茶的技術㙅作法。

植物生理學研究所正在庭活地推行延掘馬鈴

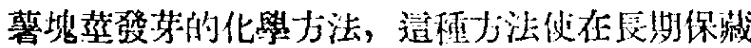

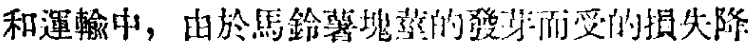

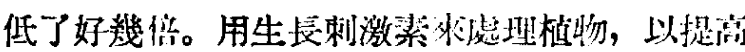

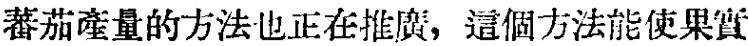
提早成熟，並䝬加產量 $0.5-1$ 倍。捉出了施用細 菌肥料和酸物肥料的綜合方法，將能薙著地提漓 農作物的喾量。

中央植物園所創造的高座量、抗倒伏和抗䡒 病阿鹅冠草小麥雜交品種也在推廣小。第 599 啹

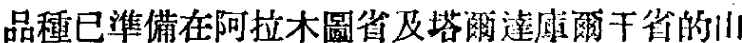
蹦地帶播種。

植物學研究所研究出了在播種前用砳酸庭理 種子的方法, 這程方法所需要的淜酸, 只及施用 明肥到土壤中的方法的1/500。

林學政究所已在生產佟俳下進行武䮑森林止

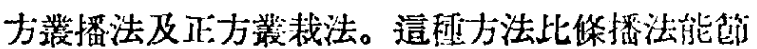
省用在婆顧播程上的勞動力 $1 / 2$ 至 $2 / 3$ 。

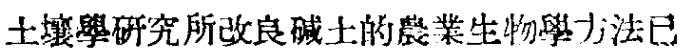

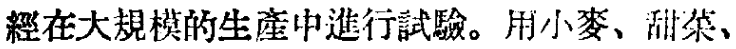

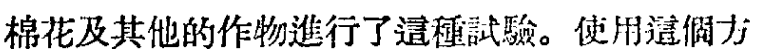
法後, 在一切地帶, 包括乾旱地帶在內, 各租作 物都獾得了盗座。

動物學研究所根據對遠東各游的動物和類及

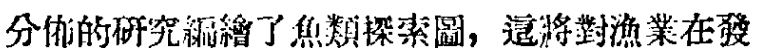
現魚的聚集方面㜂助極大。

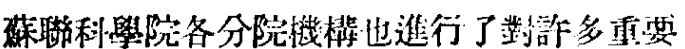


閵題的研究，它們工作的 $40 \%$ 是配合農業需要 的。它們研究天然牧場的植被及土壤琵被作第改 進牧場的科學依據。它們找喆通過培有新種爽提

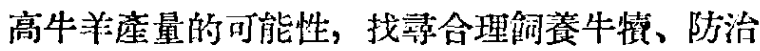
不育病和培多動物寄生病的方法; 研究提高水勧 魚產量的方法; 選擇和創造新的在當地條件下產 量高的婜鈴著和蔬集品整。

對畜牧業和漁業問題的理論研究 是落後的 (生理學研究所、動物形態學研究所及其他研究 單位)；對非黑土地帶農業發展問題亦沒有 展開 必要的研究 (土壤學研究所、植物學研究所、植物 生理學研究所及其他研究單位); 對微量元 素在 提高農作物和農音產量中的作用、動植物的營飬 理論和越冬性間題研究得很少。

生物物理罢研究所對在正常情况下，以及在 物理因素影響下生物體內所進行的生物物理過程 研究得很不够, 踓然這樣物理過程的知識對陧解 生物現象本身，以及對膫解來自外界物理影響的 特性來說, 都是必要的。

生物學部委員會的工作組織得還不够好。生 物科學是負有幫助農業的使命的, 但至今在討論 生物科學的重要問題時, 並不是所有學部委員都 來參加。

同時也㤫該指出：由於生物繁部和分院各科

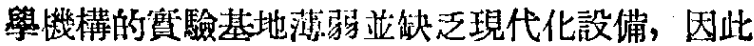
很多的科學研究不能得到必要的發展。

\section{动皐科翼的}

建策在認戨社會生活的唯一正確的馬克思列 密主笔方法的基礎上的蘇聫社會科學，以它的思 想理論水平而言，資娾階級的社會科學是决不能 與它相提並論的。正當帝國主義的思想家恬不知

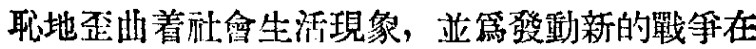
思想上進行着淮備時，蘚聯利學家却正在篇孚取 全世界和平和䍵取共產主義在我國的勝利的高向 事業而楻爭。

以戰無不勝的馬克思、恩格斯、列察、斯大 林的學說雼指針，蘇距的經濟學家、歴史罢家、

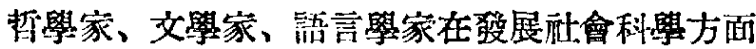
作了E大的貢獻。

但是應該直率地指出: 我門的各個人文科學

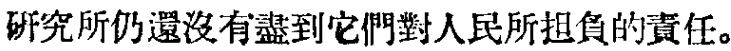

共産主義建設事業迫切要求及時研究經源、 哲學、法律、國際關係等娵重要阙題及大大地改

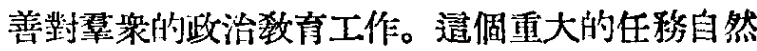
是落在集中於萑聯科學院的幾個社會科學研究所 的身上了。可是這些䂙究所在幫助解决經湾和文 化建設問題方面，在等助我門的幹部掌握革命理 論方面，還是做得很不够的。敎佟主義和菁副子 氣，對學衆和黨在歷史上所起的作用佔部不足和 個人崇拜，所有逼些都使科學院人文科學研究所

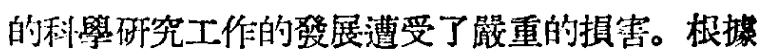
黨的指示所淮行的漫些研究所的败組帶爽了良好 的結果, 不過, 這嚾僅是一個開始。

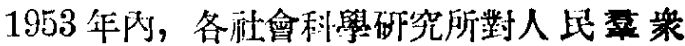

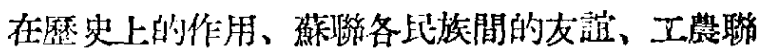
盟等這頪重要的問通溥一拿著作也没有發表過， 對雚聯的外交政策和爭取和平等閔題也很 少研 究; 對束方各是族尤其是瑟不多佔世界人口年數 的中國和印度的歷史、現代生活及其梐等也洞述 得不够。這些事貫說明逜些研究所的落後。

科學作品的思想性與文學性還不能强。部多

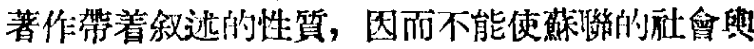
諭感到满意。同時還存在着出版劣等質量的罟籍

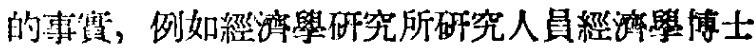
M. B. 科眮哈榙夫的著作“社會主義所有制”這本

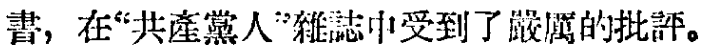
在這些研究所內很少探用利檪討論的方法, 同時批評與自我批訣也也開展得不够。

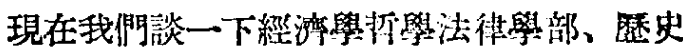
學部和交學語言敟部所完成的一些最重要的工 作。

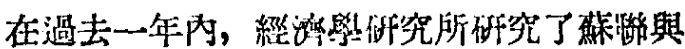

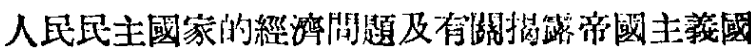
家的愦張政策等問題。1953 年經游學研究所所蔡

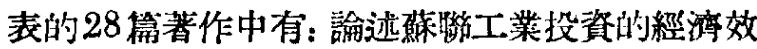
果、第二次世界大戰後帝國主義經㜔與政治基本 問題、資本主義國家經摔手册等專著。

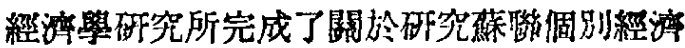

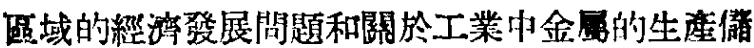
借定額等閔題的詐多重要的任務。

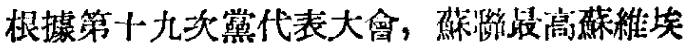
第五次常會和蘇共中央九月全合的決議所提出的

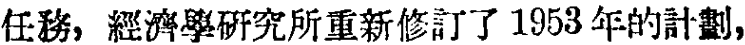


以加强䍈促進薜業和工業商品與糧食商品生產迅 速高湲的問題的研究, 並使磁究工作與共産主義 建設的實践緊密聯系起來。

踓然如此, 䌈濟學研究所低然嚴重地落後於 贵際，對社會主我經游問題研究得還不够。不久

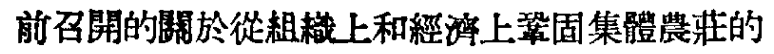
科學會議登明: 經洧祭研究所的工作没有聯系一 定的區域,關於農業和工業的研究工作没有重點,

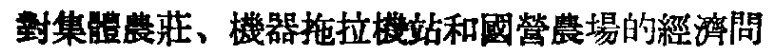
題没有進行深入的棕合性研究, 同時在提高農業 方面没有給予它們以必要的虽際期。

晢學研究所出版了辟證唯物論数本，重新修

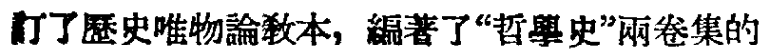
第一卷。但是哲學研究在 1953 年不但没有增加 出版量, 反而是減少了出版量。

法律學研究所完成的工作中, 有“國家和法律 的理論”致本與“政治學史”兩突集的第一然。但法

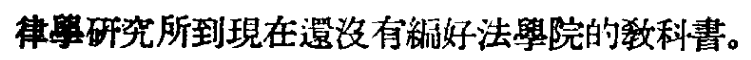

在歷史科學方面首先應當指出已經出版了關 於烏克箱重新合併於俄羅斯三百周年的三然文件 集。逜些女件說明了十八世紀烏克蘭與践释斯之 間的友誼的舫固，1648 年與 1654 年間的民族解

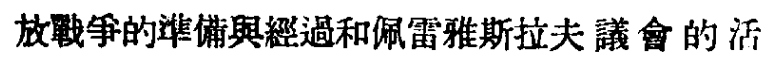
動，正是這一議會固了兩大兄弟民族重新合倣 的厢史性事件。

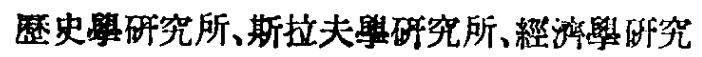
所和世界文學㸴究所所進行的許多工作都是與烏 克苚重新合併於俄羅斯三百周年紀念有關係的。

孚了这個紀念日，準啃召開專門性科學會議。

還應指出 1953 年出版的兩参蘇聯史大絧、 “莫斯科史”第二缭、“俄羅斯瑟術史”第一卷等著 作。1951 年在諾夫哥释得地方進行考古發掘時所

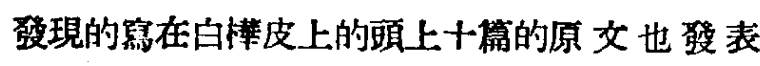
了。造些原文說明了諾夫哥羅得從十一世紀到十 四世紀時的歴史，同時證明了古俄羅斯文化的高 度水平和古代諾夫哥羅得市民上是有交字的了。

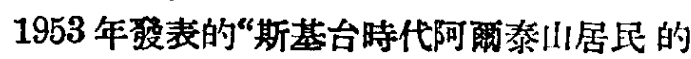
文化”專著揭等了從前一點也不知道的在斯基 台一限丽瑪地時代（公元前四世紀到三世紀）阿 爾泰山居民的生活和生活情况的景象。

物筫文化史研究所的克里米亞考古除在克里 米亞一個山洞中（靠近斯大羅塞里也村）發現了
舊石器時代前期的人的遺䯓，這種遺䯓表徽了從 內安得塔爾人種到現代人的過渡形態, 造是一個 對科學極篇重要的成果。譄個發現對解决在我們 國家目前所處的領土上的人的現代形態的形成問 題是有重要的科學意義。

但同時厢史學部內科著十缭本的“世界史”的

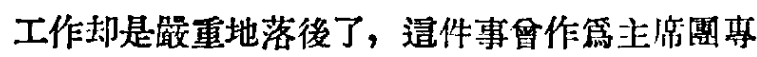
門討論的對象。歴史學研究所沟有完成高等學校 本的編著計劃，蘇聯注會史和外國現代史大規 模研究的淮備工作依然摆做得不够。

在東方學研究所內，所的領導機構的具體领 运工作在很多方面做得很不好。因此引起了不能 完成計劃和工作中的品重缺點，這些缺點也就妃 碍了該所真正地成第蘇聯東方學的科學小心。

語言學方面的工作進行得很成为。

語言學研究所完成了 20 種科學著作，背中應 該指出的有: 理論性的交集“文法絬構閣題”、論 俄羅斯標點彷號的專著和巨著“德國方言祭”。這 部巨著是對德闻語言中方言的整史性的研究。東

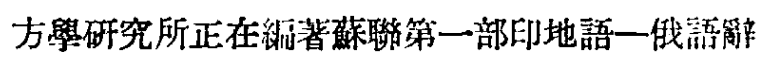
典, 娈将促進對印度最流行的一種語言的硼究。

在交學碑究方面, 1953 年完成了十鉒巨著 “俄羅斯交史”的蕉備工作; 經過了長時的間斷

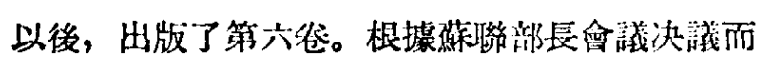
開始的科矂院版别林斯基全集的出版工作已有很 大的進展 (出版了三突)，応克蘭和向俄維撕蘇維

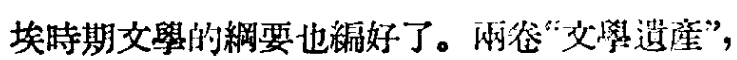
其中亦包括提克斯洛伐克共和國政肘燋給蘇聯科 學院的赤雨哭和奥加列夫的“布拉格丵書”的材料

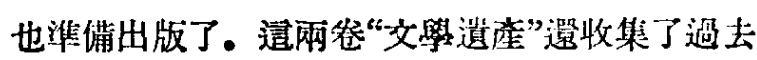
不知道的十二月黨人作家們的一些作品, 這也是 很有科學復做的。

文學語言學部工作中最嚴重的缺點是遠遠地

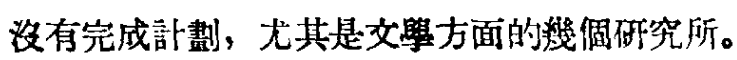
出版界巳公正地批評了運些研究所，因第他們不 可容忍地拖延了“俄羅斯蘇維埃時期文學史大䋧” 的準備工作，並在出版俄羅斯經典著作時犯了錯 誤。論文集“蘇聯戲劇創作問題”泌能按時縓好, 有 閶重要著作“交算理論的基本問題”的工作到1953

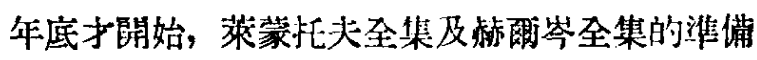
工作也沒有完成計劃。

世界文學研究所一年来评的版了网部著作。 


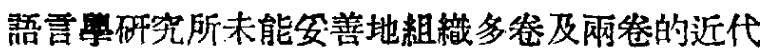
俄羅斯文學缸等的售借工作。也有對完成計劃任 務抱不嗮責任的態度的情形，例如世界文學研究 所高級研究員 B.O. 彼卓夫就至今未能提交論馬雅 柯夫斯基的一本高著,雖然已經爫它工作了三年。

交學語言學部的各文學研究所之間始終還沟 有緊密的業務上的聯㗨。學部和各所至今没有安 善安排集體性的工作，特别是關於“俄羅斯交 批部史”的工作。

在1953年蘇聯科學院各分院蕉備了許多社會 科學方面的預僃發表的著作。出版了第一集“莫爾 達維亞史”及第一集“鞋靻蘇維埃社會主義自治共 和國史”。吉爾吉斯分院討論並出版了“吉爾吉斯 蘇維埃社會主義共和國史”第一然的原稿，“吉爾 吉斯語語法”(第一册) 已準備出版。科米分院完 成了科楽著作“科米蘇維埃社會主義自治共 和 國 歴史大綱”, 師範學院用的科米語敉科書已付印。

我門社會利、學各㸴究所必須發揮全部能力, 更快地克服目前在研究蘇聯人民的生活與需要所 提出的各項迫切問題中所存在的落後現象。

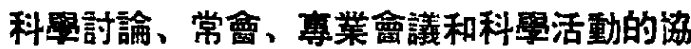
調: 大家都知羊，科學討論和自由交換意見對於 順利地開展㸴究工作具有如何重大的意義。在下 面提到的 1953 年組織的有關許多重要 問題的討 論、常會和報告會就是很好的例子。

經湾學硼究所會舉行了關於從組織上和經湾 上潖固集體農莊的問題的會議。各加盟共和國的 經濟學研究機構和蘇聯農業部的工作人員以及集 體農莊和機器拖拉機站的先進人物都積極地帘加 了還次會議。會上研究了增加農痤品産量, 增加 集體農莊收入，提高集體農莊和莊員的物質福利 和更加充分地利用技術等問題。經濟學研究所當 前的主要任務就是如何深入地研究農 業 經 濟 問 題，並給予集體農莊和國營農場以應有的惩助。 全蘇自動調整理論會議分析了造個領域內的 工作情况，並擬定了今後研究工作的主要方向。

戠乎所有研究岩石學的巨大的研究、生產機 粠都有代表參加在 1953 年召開的岩石學會議。會 上主要的報告是關於花南岩的成因和花菵化作用 方面的問題。

關於地下水的形成問題的會議，批判地研究 了䢐方面的一切主要問題，並確定了今後工作的
方向。

在絡合物化學會議上討論了絡合物中對位影 鄉的規律性，研究了絡合物的結構和性質以及已 確定的規律性在賽際應用上的一些問題。

在一次特別會議上，討論了在各個化學領域 中確定化合物概念的一些主要問題，並就邆些問 題通過了一些决議。

曾舉行了關於蘇維埃時期農業史問題的常 會,關於 1861 年改革前俄羅斯生產力和生產關保 的衝突問題的討論和關於人民詩歌創造問題的 議等等。

有許多會議是学了協調蘇聯科學院和加盟共 和國科學院的科學研究工作而組織的。通些會諳 是用桃相互介紹科學上重要問題的硼究情况和铲 展前途, 確定這些研究工作的首要任䅂和階段, 討論現有缺點，並就 1954 年的科學研究工作計䴖 取得一致意見。

各加盟共和國科學院科學活動協調委員會在 1953 年曾致力於完成兩件事: 在最重要的問題上

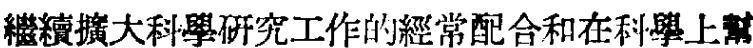
助各加盟共和國開展業務。

由於在全面配合的計劃的基礎上一致行動的 結果, 在許多最重要的科學問題上取得了重大的 科學成果。如在石油方面，取得了繁於許多單體

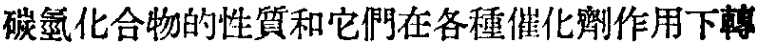

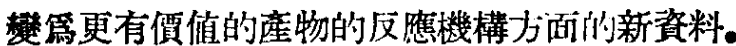
在“化學和固體燃料工熬學”問題方面，無論在焦 化的新技術方面，以及在固體燃料氣化和牛焦化 過程的理論基礎方面都獾得了新的資料。

從各個科學領域內都可以舉出上面提到的那 種例子。上面所說的研究成果中，有許多都是莉

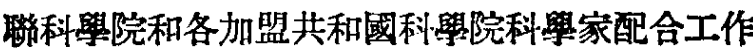
的結果。

蘇聨科學院和各加盟共和國科學院組樴的終 合工作榢，在 1953 年會給予白俄羅斯、塔吉克、 立陶宛科學院以重要的科學的譩助, 並擬就了進 一步墢展上迅各科學院的科㧳工作的措施。除類 似逼樣的工作隊外，個別的科學家們賟到各加盟 共和國科祭院去予以科算的势助。

但是，應該强調指出，在蘇聨科眾院一些機 構中先進的創造性的討論方法以及科學工作的協 調還没有得到碓有的進展。我們科䁷院的科學家 
閒也還沟有公分地聯合起來，努力去解决利舉上 最重要的問題。直到現在, 在某些問題上還停留 在表面的或形式的配合。這在頗大程度上是和生 物學鄚、物理學新學部、化學部的協調工作有關。 科學活動協調委䝿會和蘇聯科學院生物學部沒有 探取必要措施, 以保証有關許多極重要的生物學 和農業問題的科學研究工作的經常的協調。

出版工作 逗是蘇聯科學院工作门的一個重 要部門。利罳院的出版物不僅是科學家關於自己 工作的一種廣泛的公開報告形式，而且世是将逜 些科祭工作的成果推廣到全國的生產和文化事業 中去的一個重要方法。

1953 年科㑹院科學出版物的數量有了很大 的增長，共計約澾 15,000 個著作项。我們的出版 局完成了著作更計劃的 $102.3 \%$ 。

1953 年的出版物中有許多科學、政治和國民

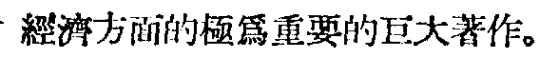

在極雼短促的期限內出版了“烏克蘭重新合 例於俄羅斯”三卷交微與資料，出版了“莫斯科史” 的第二悉、“俄羅斯藝術史”第一急和有啙富的圆 片的“證狩與工業獸類圖”及其他書籍。

在所有出版物中, 期刊佔有非常大的比重, 1953 年出版的 44 種期刊的签幅 在 4,500 倜著作 页以上。在1953年完成了極拿複雜和困難的科學 文摘的最初幾集的出版。不久之前成立的利學報 導處進行了出版科學交摘的声大渠借工作，这個 機構已在 1953 年完成了化學、数學、力學、天文學

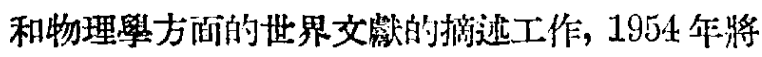
要摘述地質學、地理黌、生物學和某些技術部門 的交钭。毫無疑問，科學文摘在今年內即將成第 每一位科舉家的珍貴參考資料。

在蘇共中央九月全會以後, 1953 年內有關農 業方面的出版物已有增加; 但這一方面的工作仍 然是做得很少，特别落後的是通俗科期丵書“農業 須知"的緛基工作。

生活本身、國民經济的需要和蘇聯科學院工 作量的不断堆長都迫切要求科學比版物的坦加。 因此必須談一談出版事業中的重要缺點, 這些缺 點的消除是出版事業攄大和改善的先决條件。

在邅些最重大的缺點方面, 首先是執行計劃 的毣格性不够, 由於這個原因, 在選題計劃中就 產生了許多用另外一些著作來更換某些著作的現
敬。在選題方面，1953 年的計㜢更 動了 $20 \%$ 以 上。

直到目前第止, 出版局還不時收到一些不宜 於出版或紑寫得很落的稿件，這些稿件事後都要 經過很長㭙期的修改。例如人種學政究所緛寫的

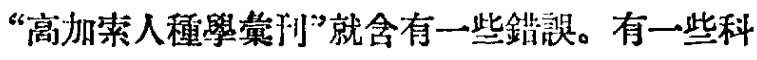

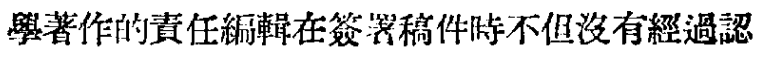
真的審校，而且對著作的內容也了解得不够。各個 硼究所對稿件所提出的評論有㭙是十分形式的。

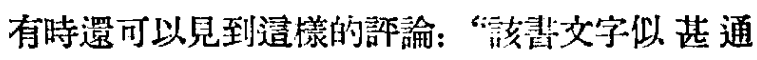

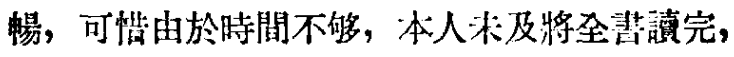
對該書是否必須悉校，沟得任便確切的意見。我 建議這本書應該出版, 並且是越快越好。…...”

遭個例子說明, 在科學院的某些單位內人們 對科學著作的出版仍舊探取一種不䍃責的態度，

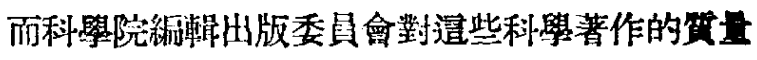
也控制得不够。

最近紋年來科學院仙版書籍的本均篇幅正在

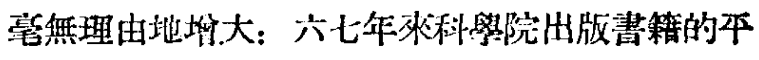

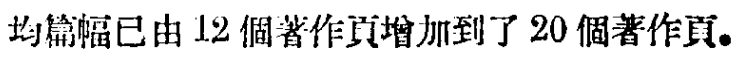
顯然, 各個研究所、科學院縓軲出版委員會和出 殿局對付印著作在篇幅力的的要求已經降低了。 特別，在最近幾年中出版了各種各樣的會議資料， 在這些資料襄刊载了許多的報告和㡎寻等等, 而 不是根據造些资料提供一些第科學和筫践所需要 的精簡的總結性的著作。有些原稿在出版局䠶闇 過久。

改進各研究所裏編寫稿件的工作，仔細地挑 選那些储得發表的著作，取消那些多餘的著作， 消隇重排和根本改竄的現象, 所有㯰一切都能大 大地撗克科學出版物的蛽際數量。

主席團和各部對分析科學院各單位所出版 的刊物的活動没有予以足够的注意。雖然潐備出 版具有高度思想理論水平的科學期刊是各學部和 研究所的重要任䅂。

科男幹部 1953 年蘇聯科與院在改淮中央 各研究單位及各分院科學幹部的選拔、調配和培 養上做了很多工作。在這方而最重要的是去年 1月 16-17 日, 所舉行的有關幹部工作問題的科 舁院積極分子會議。在這次會議上聽取了並討論 了蒜聯科學院院長 A. H. 湟斯米掦諾夫院士“在 蘇聯共產黨十九次代表大會的決議的啓示下, 論 
消隇蕉聯科祭院幹部工作中的缺點的一些措施” 的報告。

1953 年, 在科學院生活中一件很大的事情就 是選出了詐多新院士和通訊院士。

逪次選舉充貫亚加强了詐多有發展前途的科 學部門。如: 物理學中的最重要的部門、天文學 和天體物理學、無線電技石，電子學、自動機械 學興遗距離操緃機械學、動力工程學和水力工程 學、化學、普通地質學、地球化學和地球物理學、 結晶化學和結晶物理學。在社會科學方而，如政 治䋊濟學、蘇聯㷴史、哲學等重要學科亦獲得了

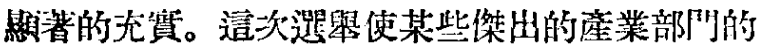
科學家參加了科學院。他們參加科學院工作，將 加强科學機關和生產部門的聯系。

和過去那㙨年一樣, 1953 年科學院在㑲部數 量上, 有了不斷的上外: 一年中利學候補博士增帅 了 322 名, 沟有學位的科學工作者坦加了588名。

1953 年在加强科學院的領導幹部方面，会經 淮行了重大的工作。1953 年10月26日藇行的科 學院全體大會, 選舉了新的科䑁院主席團, 推選 了 6 名學部院士秘㫪。並在逼一年中改選了科學 院全部 8 個學部常喺委員會。1953 年在科學院有 65位科學工作者被提声參加領導工作。

蘇聯科學院各單位，在 1953 年通過研究生 院和博士生院的方式，大大地改善了科學幹部的 堛䔲工作。在研究生院中有 525 名在本科結了業 業, 其中 317 名已通過了候補愽士的論交答掊, 106 名已經提出答棓論文，102名已結束了基本 理論課程。與 1952 年比較,通過候補博士論文的 人數，增加了 $67.7 \%$ 。

此外，在 1953 年份有 70 名研究生經過科䡒 院各研究㽞位的暫代培食制度，已通過了候補博 士的論一文答㖕。1953 年在科學院總共唔養了 515 名科學候補博士。

在這期間有 114 名科學院的博士生通過了論 文答撴。除趼究生院及博士生院以外, 向有 148 名 和 73 名科學院的科學工作者分別通過了候補博 士及博士的論文答㨱。

1953 年科學院已完成了研究生院的 招生計 劃: 共招收了 847 名研究生, 其中 677 名是脫離 生啇的。

但是在培養科學幹部方面，還存在着願重的
缺點。應該争取全部學員按時結業，並通過論文 答群; 礁該特別注意改淮候補博士及愽士諭文的 質量。

國際聯繁 1953 年大大地加强了關 於 演 展 和加强與人民民主國家的科學機構及科學家們的 科學與文化聯系的工作，以及和資本主義國家的 某些進步科學家們的科學與交化聯薮的工作。

1953 年蕉聯科學院派遗了 30 個科學代表 (1952 年篇 14 個) 出國, 参加各種國際性的和某 些國家的報告會、代表大會、討論會，並對人民民 主國家的科學家給以科學技術方面的瑟助。

蕉聯科礐家參加了在加拿大舆行的第十九次 國際生理學會議，在瑞士舉行的第一三三次國際理 論化學與㮣用化學會議, 在丹麥舉行的第十四次 國際動物學會議，在意大利藇行的第六次國際微 生物學會議，匈牙利歴史學家代表大會，波蘭第 八次數學家代表大會，唗克人種學家討論會及其 他部多科學性的接触。

在 1953 年中，有 14 個外國科學家的代表圄

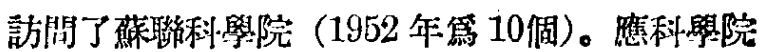
邀請前來我國訪䦐的有中國、朝鮮、唗克、民主 德國、匈牙利、波蘭、羅馬尼亞、保加利亞、英 國、意大利、茄蘭、日本等國的科舉家。

與國外科學機構的圖娈交換工作也有了顯著 的增强；其中等先是與人民尼主國家的交換。

蘇聯科㸚院的科學家們皘極地參加了保衛和 平的運動。著名的蘇聯科學活動家們曾多次在國 際性的保衛和平的大會上發言, 這是具有十分重 大的社會政治意義的。

上面所列舉的，還遠不是團結在蘇聯科睓院 創造性的集體中的科學家們的全部研究工作，然 㖇它也已足以䛦明科學院科學活動的規模、範圍 和某些基本的方向了。科學院的活動已一年比一 年地更接近國民經沾中各項迫切任歌，日益加添 着自己對共產主義建設的貢獻。在總結一年工作 的時候，我們應當毫無保留地指出工作中的缺 點，其目的是篇了能够更快、更徹底地 克服它 們，這樣予能琗助我們改進今後的工作，促進蘇 聯先進科學的不斷進步。

除了上面所談的各個孚部工作中 的 缺 點 以 外，同時也必須指出，很遺憾的，還有一些是奎 
院共同的缺點。

首先, 就是拖延了辝多最重要任務的完成, 道原是紹對不能尤歌的。對蘇聯各民族的文化和 國民經淳中某些迫切問題的總結工作, 我們做得 造是不够。

巳完成的研究工作的推廣也還遠不够順利， 特别是在農産品保藏上有着極重要意義的冰凍倉 庫，在國民經流中推廣得很差。

技術科學部在新技術的理論問題的研究上遺 没有能起領導的作用。

在幹部的分配、培蓄以及科學組 織工作方 面，還存在着㩔重的缺點。

科學院主席图祙是按期地接受院士們關於他 們在過去一年中所完成的工作的個人的報告, 然 而既没有研究這些報告, 也沒有討論和總結這些 報告。結果我們就失去了推廣先進經驗和科學成 就的重要來源, 失去了對缺點及時提出批評的可 能。今後須要適當地組織這项工作。

1953 年我椚通過了一项非常重要的决議, 就 是要整理我國傑出科學家的科學傳記, 來普及蘇 聯科學家的成就，但事望上我椚並沒有認真執行 運項决竓。

關於減輕科學家的負担, 使他們能更多地從 事於科學研究工作和培若幹部, 依售是一個很迫 切的問題。最近一段時期來, 由於探取了一些措 施, 各色各樣的大會小會是減少了。然而科學家 的勞動組織仍然需要認置地改進和合理化。

必須重新調整一下各單位領導人、院士秘書 和副院長的職權，並作某些擴大。必須使各㠘部 常務委員會在科學院的組織系統中佔有一定的負 責的地位，使其工作兓能和主席圈保持緊密的聯 系, 同時也能與各研究所有密切的聯系。因此罣 部常務委員會的職權和責任也必須予以提高。

主席團以及各學部常務委員會通過了很重要 的, 亚且多斗是經過詳細考虑的一些决議, 但是 通些决議執行情况的檢查, 做得不够順利。主席 田、它的各機構、眾部常務委員會以及各研究所 在監督决議的執行情况上都做得美。

独聯科罳院主席團和學部的各機構應當改變 自己的工作作風。必須㗂格地精簡公文往來和報 告的篇幅。各機構的工作人員應當提高自己的責
任感，更好地恝助科舉家工作，消堿工作中的缺 點。總務機構的工作應當徽底改善, 應當把工作 做得更有效些, 更確切些, 在保䇎科學研究工作 上要是正給予有效的究助。

科眾院某些研究單位澲在職的科學人員工作 水平的提高，做得不好。由於通些單位的領道者 椚以及學術委員會對造件重要工作没有給以必要 的注意, 所以在造些比較大的研究單位, 如物理 舆問題研究所、物理化學研究所、動物形態擧研 究所、土墥學研究所等, 在 1953 年, 就没有一個 研究人員通過博士論文答群。

某些研究所的領導者對培䓹研究生、博士生 的工作很少過問。而整個科學院還很少培養農莱 以及與日用品生產有關的各學科的科部。從 科眾院研究生院及博士生院淘汰什去的人數至今 還是相當大。

1954 年毫無問題地將會是落維埃人在勞動 創造中取得新的更大成就的一年。蘇聯人民正在 盡其全力來光榮地完成他們所行臨的1大任䅂。

在實現共湿主義建設的網領和解决黨所提出 的篇提高蘇聯人民稫利的任䜶中，科學担覓着很 大的責任。蘇聯的科學應掌在世界科祭中佔據第 一位，應當給刑會主義的工業、農業和父化以跕 盛的科學成果，正如全蘇聯人民所阴残於我們的 那樣。篇了完成這個光榮而重大的任務，我們奀 當更好地工作, 更有組織地、更迅速地進行研 究, 更堅决地把研究成果付諸售践。

1953 年年末科學院的利學家們曾經與工 業、 運輸業、農業、保健事業力的的專家共同進行了 關於在最近道械年重必須研究的某些重大科學問 題的研究計劃的制訂。這是我們制訂科學計劃, 琗固科學與䝿䟠的聯系，以及協調全部蘇維埃科 學大軍的力量來完成共產黨和蕉維埃政府所交付 的任務的一個新的重要的階段。

蘇聯科學院的全體人員不會辜負人民的信 任，他們將貢踧出自己的全部力量、知識和經駺 來完成這些任移，全力促進我們偉大朔國筫力的 增長。

〔越 同 沈文建 曾肯成章宗涉等 羅自蘇距科學院通報 1954 年 3 月號了 